\title{
Biophysics of human anatomy and physiology-a Special Issue in honor of Prof. Cristobal dos Remedios on the occasion of his $80^{\text {th }}$ birthday
}

\author{
Damien Hall ${ }^{1} \cdot$ Amy Li $^{2} \cdot$ Roger Cooke ${ }^{3}$ \\ Accepted: 23 July 2020 / Published online: 29 July 2020 \\ (C) International Union for Pure and Applied Biophysics (IUPAB) and Springer-Verlag GmbH Germany, part of Springer Nature 2020
}

\begin{abstract}
In 2001, Cristobal dos Remedios was made Professor of Anatomy (now emeritus) within Australia's highest-ranked university (University of Sydney). For the majority of his career, he has examined the biomechanics and biophysics of human muscle contraction. To coincide with the occasion of his $80^{\text {th }}$ birthday, this Special Issue has commissioned a collection of review articles from experts exploring biophysical subjects within the general areas of human anatomy and physiology. After introducing the scope and contents of the Issue, we provide a short scientific biography, placing his scientific achievements within the context of the course of his life's developments.
\end{abstract}

Cris dos Remedios has played an important role in the development of biophysical research both within Australia and worldwide. Passionate about research, he has pioneered a number of molecular biophysics methodologies for the investigation of muscle contraction (dos Remedios et al. 1972; dos Remedios and Moens 1995; dos Remedios and Chhabra 2007; Mollova et al. 2013; Montag et al. 2018). Within the cardiac muscle field, he is perhaps best known for establishing the Sydney heart bank - a community-wide resource that consists of a very large sample repository of healthy and diseased patient's hearts that have a full associated medical workup and case history (dos Remedios et al. 2017).

This Special Issue is split into two general sections. The first includes a series of Commentaries and Letters that allow the authors to describe their scientific and personal interaction with Cris through the course of his career (Table 1). Contributions have been received from both present and

Damien Hall

hall.damien@nitech.ac.jp; damienhall30@gmail.com

1 Department of Life Sciences and Applied Chemistry, Nagoya Institute of Technology, Gokiso Showa, Nagoya, Aichi 466-8555, Japan

2 Department of Pharmacy \& Biomedical Sciences, La Trobe University, Bendigo, VIC 3552, Australia

3 Department of Biochemistry, University of California San Francisco, San Francisco, CA 94158, USA former collaborators as well as students at different stages of their professional and academic progression. The second section involves a collection of scientific review articles associated with Cris's principal research topic, the molecular basis of heart muscle contraction. These review articles include analysis of areas ranging from the molecular, to the tissue level, of study (Table 2). To set the scene and help place these articles in context, this Editorial provides a short history of Prof. dos Remedios's life and research in roughly chronological order ${ }^{1}$. Following this Editorial is a personal recollection by Cris reflecting on his life in research (dos Remedios 2020). Immediately after this is the fourth addition to our Biophysical Reviews 'Meet the Editor Series' featuring Assoc. Prof. Joshua Ho (University of Hong Kong) - one of the five Executive Editors (Ho 2020).

\section{An interesting family history}

As science is an international endeavour, it is relatively common to meet people from different countries and cultures. With this said, it would be fair to say that Cris has one of the more exotic cultural pedigrees likely to be encountered. The dos Remedios surname is in fact Portuguese and was inherited from his paternal grandfather Carlos dos

\footnotetext{
${ }^{1}$ The material for this mini-biography came jointly from a long history of association between Cris dos Remedios and the three authors along with a series of morning telephone calls conducted over a week in April of 2020.
} 
Remedios. Carlos was a Portuguese national who traded between the Spanish port of Barcelona and the major Japanese port of Kobe in the late 1800s (soon after Japan opened to the outside world). Honoured by the Spanish government for his efforts in expanding this trade route, Carlos was granted a minor title and Spanish citizenship. At the turn of the century, he married a Chilean woman who sadly died in childbirth, but years later he met and married a Japanese woman, Kimurasan, in Kobe. At that time, marrying a non-Japanese person meant that Kimura-san had her Japanese citizenship withdrawn and literally became a stateless person under Japanese law. The marriage meant she became Spanish but without any citizenship or passport; she was unable to leave Japan (this situation persisted well into the latter part of the twentieth century). Happily, the union produced two children, Maria Franco (nee dos Remedios) and Carlos Guillermo dos Remedios, the latter being Cris's father. The family settled in Yokohama where they lived in relative comfort with their children growing up in the rapidly changing environment of Japan in the first half of the twentieth century ${ }^{2}$. Carlos entered the family trading business and eventually met and fell in love with Joyce Lillian Taylor, the daughter of an English Professor of Economic History in Tokyo. Carlos and Joyce were married in 1937 just a few years before Japan entered World War II. The outbreak of war and the polarization of society that accompanied it was not kind to Cris's parents in their pursuit of a happy married life. Identifying as a Japanese, Cris's father felt obliged to remain in Japan to look after his American friends who were interned there. Carlos' Spanish citizenship meant he was free to remain in Japan but due to her English citizenship, Joyce was deemed persona non grata and given a limited time to leave the country. This she did together with her eight-month-old son Cris, her younger sister Brenda, and her Mother Mary and Father Ronald (REM Cameron) on the steamship 'The Ruys', one of the last commercial vessels departing from Japan for Sydney, Australia. Arriving with her newly born son in an unfamiliar country in 1940, Joyce set about starting a new life, as the Second World War in the pacific began in earnest.

\section{Early schooling}

Life was not easy for Joyce as a young single mother in Sydney. Taking a job as a teacher, she raised Cris whilst Australia was mobilizing to fight alongside Britain in Europe and the USA in the Asia Pacific region. Despite being separated from her husband and considering the marriage to be non-repairable, she had nevertheless promised Carlos that Cris would be raised as a catholic (despite herself identifying

\footnotetext{
${ }^{2}$ Indeed to this day, family plot of headstones resides in a Yokohama shrine under the dos Remedios name.
}

as a member of the Church of England). With limited funds and location requirements, this meant that Cris's earliest schooling was carried out at St. Vincent's catholic girl's school with Cris enrolling as the school's only boy pupil. As he got older, he transferred to Campion Hall - a slightly further afield Jesuit primary school that was, to his great delight, solely for boys. Inevitably however his Japanese heritage leaked to his classmates and the children, with child-like reasoning, sought to extract some rough justice for what they perceived as his shared responsibility for the recent war in the pacific. During the interview process for the preparation of this Editorial, Cris was asked what he did to curtail the beatings suffered on the playground. In what may be a particularly insightful answer, Cris remarked that he set about forming his own gang that were, on the whole, collectively tougher than his playground detractors - after which bullying became increasingly less of a problem! This primary school 'gang' became a close-knit and highly loyal group of friends that he kept throughout junior and senior high school. Along with this group, Cris entered Marist Brothers North Shore Jesuit High School and it was here that he received an excellent introduction to the sciences ${ }^{3}$ which helped to propel him into Australia's top university, the University of Sydney.

\section{A peripatetic academic beginning}

After finishing high school, Cris signed up to perform mandatory national army service. However, upon turning eighteen, Australian law mandated that he take the citizenship of his father-so Cris found himself a Spanish citizen once again. Before entering national service, he was required to become a naturalized citizen ${ }^{4}$. In a somewhat anticlimactic fashion after becoming naturalized, the army service requirement was cancelled allowing Cris a straight path to university. Cris was admitted to study medicine; however, after completing three years of a six-year course, he realized that he was not naturally suited to caring for the sick. Upon attending a lecture by John Eccles ${ }^{5}$ on neurophysiology, Cris made the decision to change his enrolment to science which, with prior credit, he obtained in two years. Upon suggestion from his undergraduate mentor, the noted geneticist and population ecologist Prof.

\footnotetext{
${ }^{3}$ One particular memory of note was the introduction of television to Australia during Cris's primary and secondary schooling. School teachers expounded how information was sent via radio waves and decoded using a cathode ray tube. This very practical application of science fostered a keen interest in the topic within Cris.

${ }^{4}$ Cris recalls talking with the Lord Mayor at the naturalization ceremony. Upon hearing so many of the recipients talking, like Cris, in thick Australian accents the Lord Mayor inquired as to why they were naturalizing so many Australians that day.

5 John Eccles would later be awarded the 1963 Nobel Prize in physiology and medicine (together with Andrew Huxley and Alan Lloyd Hodgkin) for his work on the action potential mechanism of nerve impulse transmission (Eccles 1963).
} 
Table 1 Commentary/Letters in this Special Issue 'Biophysics of human anatomy and physiology — a Special Issue in honor of Prof. Cristobal dos Remedios on the occasion of his 80th birthday'

\begin{tabular}{|c|c|}
\hline Title & Reference \\
\hline $\begin{array}{l}\text { 1. Editorial: Biophysics of human anatomy and physiology - a Special } \\
\text { Issue in honor of Prof. Cristobal dos Remedios on the occasion } \\
\text { of his } 80^{\text {th }} \text { birthday. }\end{array}$ & Hall et al. (2020) \\
\hline 2. Letter: A Career in Biophysics. & dos Remedios (2020) \\
\hline $\begin{array}{l}\text { 3. Editorial: Biophysical Review's 'meet the editors series' - } \\
\text { a profile of Joshua W. K. Ho. }\end{array}$ & Ho (2020) \\
\hline $\begin{array}{l}\text { 4. Commentary: Cris dos Remedios: Sydney Heart Bank and } \\
\text { Scientific Mentorship beyond } 2010 \text {. }\end{array}$ & Li (2020) \\
\hline $\begin{array}{l}\text { 5. Commentary: Recollections of my Ph D. Research in Professor } \\
\text { Cris dos Remedios' Laboratory. }\end{array}$ & Berry (2020) \\
\hline $\begin{array}{l}\text { 6. Commentary: In Honour of Professor Cristobal dos Remedios } \\
\text { on Behalf of The MAWA Trust. }\end{array}$ & Watson et al. (2020) \\
\hline 7. Commentary: Thank you (Obrigado) Cris and happy Bday (Parabéns)! & Sequeira (2020) \\
\hline 8. Commentary: Professor Cristobal G dos Remedios mentorship. & Bao (2020) \\
\hline $\begin{array}{l}\text { 9. Commentary: Fond Memories of my PhD Research in Professor } \\
\text { Cris dos Remedios' Laboratory. }\end{array}$ & Kanellis (2020b) \\
\hline $\begin{array}{l}\text { 10. Commentary: 'Muscle superman' Cristobal Guillermo dos Remedios: } \\
\text { Five decades of endless energy. }\end{array}$ & Braet (2020) \\
\hline 11. Letter: Studies on the impellers generating force in muscle. & Ando (2020) \\
\hline $\begin{array}{l}\text { 12. Letter: Sydney Heart Bank: a core facility that goes the extra } \\
\text { mile to advance cardiac research. }\end{array}$ & van Dijk (2020) \\
\hline $\begin{array}{l}\text { 13. Letter: Research Exchange with Cris: From Fluorescence } \\
\text { Spectroscopy to Human Myocardium. }\end{array}$ & Ishiwata (2020) \\
\hline 14. Letter: Hactive: A smartphone application for heart rate profiling. & Goldberg and Ho (2020) \\
\hline 15. Letter: Cris dos Remedios; a Driving Force in Muscle Research. & Bennett (2020) \\
\hline $\begin{array}{l}\text { 16. Letter: Prof. dos Remedios and the Sydney Heart Bank: enabling } \\
\text { translatable heart failure research. }\end{array}$ & Holmes and Stelzer (2020) \\
\hline 17. Letter: Cardiomyocyte renewal in the failing heart: lessons from the neonate? & Derks et al. (2020) \\
\hline $\begin{array}{l}\text { 18. Letter: Cris never left you wondering about where you stood! } \\
\text { His motto was: Just do it! }\end{array}$ & Dedova and Kekic (2020) \\
\hline 19. Letter: Barriers to sun safety in autism spectrum disorder. & Kanellis $(2020 a, b)$ \\
\hline
\end{tabular}

Charles Birch, Cris was encouraged to enrol in an Honours Degree in Physiology. Upon graduating with a first-class degree, he then undertook a PhD course supervised by Prof. Darcy Gilmour on the topic of the filament structure of muscle (Fig. 1). Cris describes Gilmour as an iconoclastic intellectual and in this spirit, he set Cris the ambitious project of determining the microscopic filament structure of skeletal muscle isolated from the common mud crab using an electron microscope (EM).

As Cris recalls the story, his first challenge was to get time on the electron microscope of which the department had two-a low-resolution Siemens Elmiskop 1A and a higherresolution Phillips 200. In what would be a recognizable situation to many experimentalists, the facility manager fiercely guarded the two machines, making it hard for a novice to gain familiarity with the equipment and the much needed time to investigate freely. To overcome this problem, Cris enrolled the help of the microscope engineer Bob Wright, who Cris persuaded to train him in the usage of the EM from $6 \mathrm{pm}$, after the facility manager had departed for the day. Proceeding in this way (working the night shift), he became experimentally adept in operating both devices, mastering sample preparation, microscope setup and alignment, image capture, and (at times) emergency repairs running to an 8-am deadline! When Cris reached a resolution limit due to the staining protocol he was using, he independently reached out to Edgar Mercer, an electron microscopy expert located at the Australian National University. Travelling on his own initiative to Canberra for a few weeks, Cris received instruction on a superior single myofilament sample preparation and staining protocol based on the use of ammonium molybdate. Cris's remarkably well resolved longitudinal and transverse EM images suggested that, in addition to the thick (myosin) and thin (actin) filaments, a third unknown filament may be present within the basic myofibril structural unit'. To further investigate his 'residual filament hypothesis', Cris sought time on a higher energy laboratory-built electron microscope housed within the department of physics. With his somewhat clandestine nighttime usage of the high-resolution EM, his improved staining

\footnotetext{
${ }^{6}$ Cris's observation of a third or 'residual' filament was later shown to be correct with this third filament being composed of titin - the largest protein in the human proteome (dos Remedios and Gilmour, 1978; Maruyama 1997).
} 
protocol and his borrowed time on an experimental device in a different department, Cris was able to finish his $\mathrm{PhD}$ thesis in three years (dos Remedios 1965). This was considerably less time than what was considered standard within the Department of Physiology at that time. On recalling his $\mathrm{PhD}$ experience, Cris credits both Gilmour and Birch for instilling in him a sense of the need to carefully formulate his own hypotheses and solve these problems in an independent fashion ${ }^{7}$.

\section{Starting both a family and an academic career}

During his PhD studies, Cris met Trish Harrison, who would go on to play the most significant role in his life - as his future wife and mother of his four children. A daughter of a renowned local family ${ }^{8}$, Trish worked for the Sydney branch of Vogue magazine. She met Cris at a party whilst he was still attending medical school and the two soon started courting. Cris recalls having to apply all his charm to overcome his future in-laws' sense of trepidation about having a 'foreigner' dating their daughter. However, things progressed and the young couple married in 1964, with their first son Nick born in Australia during Cris's PhD write-up period in 1967. Cris and Trish went on to have three more sons, Dominic (born 1971), Benedict (born 1978) and Oliver (born 1982).

Towards the end of his $\mathrm{PhD}$, Cris applied to the American Heart Foundation for a postdoctoral fellowship to be carried out in Prof. Manuel Morales laboratory at the University of California San Francisco. Although successful in obtaining the fellowship, the award came without travel support. Fortunately for Cris, he was offered a junior lectureship in anatomy at the University of Sydney by the head of his department (and former mentor) Prof. Charles Birch. This allowed him to save sufficient money to cover the relocation of his new family to the west coast of America. Even at that time, the cost of rent in San Francisco was not commensurate with a scientists' salary and Cris recalls having to spend $70 \%$ of his fellowship monies on a small one-bedroom apartment.

Despite Prof. Morales having a reputation as an authoritarian, Cris both enjoyed working with him and the scientific life in the group. Equipped with the latest equipment, the laboratory was staffed by postdoctoral fellows only. With no students to assist the young postdoctoral cohort could really concentrate on serious research. Cris continued his research topic of myofibril structural analysis but employed new techniques based on electron paramagnetic resonance (EPR) (Barden

\footnotetext{
${ }^{7} \mathrm{He}$ also fondly recalls the advantages of choosing a project that allowed him to hold a regular cook out of left of mud crabs served with white wine of each Friday for his fellow student cohort.

${ }^{8}$ Trish's grandfather, Jack Harrison, had represented the state in both cricket and rugby which in sports mad Australia provided her with minor celebrity status.
}

et al. 1980) and various forms of fluorescence microscopy that included fluorescence photobleaching methods and fluorescence polarization techniques (dos Remedios et al. 1972; Botts et al. 1973). During his postdoctoral fellowship, Cris formed many close friendships with other postdoctoral and visiting scientists, with many of these contributing to the current Issue.

Of particular scientific note during this time was Cris's research into:

(I) Intrinsic tryptophan fluorescence studies of actomyosin function. Cris noted that a single tryptophan existed in the 'head' region and that this lone intrinsic fluorescent label could be used for localized structure function experiments (dos Remedios et al. 1972).

(II) FRET studies of actomyosin contraction that helped to provide some of the earliest precise distance information between actin and myosin proteins (dos Remedios and Cooke, 1984; dos Remedios and Moens 1995).

An interesting story recalled by Cris about his stay in the Morales laboratory was his refusal, on one occasion, to include an additional author on a scientific paper that was being jointly written with the laboratory chief Morales. Cris's feeling was that the scientist in question had not made a significant contribution. This put Cris in direct conflict with Prof. Morales - a seemingly untenable position. However, instead of giving up, Cris organized a discussion over dinner where he made his case calmly and without rancour, after which Morales relented. As many realize, such determination to take a stand on principal is not always advantageous to a scientist's career advancement; however, in this case, it served Cris well and the interaction led to a greater personal respect for him from Morales.

\section{Return to Australia}

Notably, Cris's work on the use of intrinsic fluorescence for the study of actomyosin function led to him receiving the Louis N Katz Prize for young researchers from the American Heart Association. Partly due to the notoriety associated with the winning of this award, Cris was approached by a senior colleague of Morales working in the Mayo Clinic at the University of Minnesota and offered a tenure track position. At roughly the same time, he received a telegram offering him a lectureship in anatomy, at the University of New South Wales. After a discussion with his wife, Cris realized that it was time to return home but managed to use the Minnesota offer to negotiate for an upgrade to a Senior Lectureship position at UNSW. Returning in 1972, he received both Australian Research Council and National Health and Medical Research Council grants to support his Australian 
Table 2 Scientific reviews in this Special Issue 'Biophysics of human anatomy and physiology—a Special Issue in honor of Prof. Cristobal dos Remedios on the occasion of his 80th birthday'

\begin{tabular}{|c|c|}
\hline Title & Reference \\
\hline $\begin{array}{l}\text { 1. Review: Early adjustments in mitochondrial structure and function in } \\
\text { skeletal muscle to high altitude: design and rationale of the first study } \\
\text { from the Kilimanjaro Biobank. }\end{array}$ & Stienen (2020) \\
\hline $\begin{array}{l}\text { 2. Review: Donor hearts in the Sydney Heart Bank: reliable control but } \\
\text { is it 'normal' heart? }\end{array}$ & Marston et al. (2020) \\
\hline $\begin{array}{l}\text { 3. Review: Growth factor therapy for cardiac repair: an overview of } \\
\text { recent advances and future directions. }\end{array}$ & White and Chong (2020) \\
\hline $\begin{array}{l}\text { 4. Review: Insight into atrial fibrillation through analysis of the coding } \\
\text { transcriptome in humans. }\end{array}$ & Steenman (2020) \\
\hline 5. Review: Profilin: Many facets of a small protein. & Davey and Moens (2020) \\
\hline $\begin{array}{l}\text { 6. Review: Challenges and emerging systems biology approaches to } \\
\text { discover how the human gut microbiome impact host physiology. }\end{array}$ & Qian and Ho (2020) \\
\hline $\begin{array}{l}\text { 7. Review: Sarcoplasmic reticulum calcium mishandling - central } \\
\text { tenet in heart failure? }\end{array}$ & Denniss et al. (2020) \\
\hline $\begin{array}{l}\text { 8. Review: Visualizing the in vitro assembly of tropomyosin/actin } \\
\text { filaments using TIRF microscopy. }\end{array}$ & Janco et al. (2020) \\
\hline 9. Review: Disease mutations in striated muscle myosins. & Parker and Peckham (2020) \\
\hline 10. Review: Cell shape: effects on gene expression and signalling. & [Esfahani and Knöll (2020) \\
\hline $\begin{array}{l}\text { 11. Review: The RNA binding Fragile X mental retardation protein } \\
\text { and its role beyond the brain. }\end{array}$ & Malecki et al. (2020) \\
\hline 12. Review: Understanding and using AlloSure donor derived cell free DNA. & Seeto et al. (2020) \\
\hline $\begin{array}{l}\text { 13. Review: IL-34, } 36 \text { and } 38 \text { in colorectal cancer - key } \\
\text { immunoregulators of carcinogenesis. }\end{array}$ & Bao et al. (2020) \\
\hline 14. Review: The intercalated disc - a mechanosensing signalling & Pruna and Ehler (2020) \\
\hline
\end{tabular}

node in cardiomyopathy.

15. Review: The Molecular Mechanisms associated with the Physiological Responses to Inflammation and Oxidative Stress in Cardiovascular Diseases.

16. Review: Imaging tools for assessment of myocardial fibrosis in humans:

Zhazykbayeva et al. (2020) the need for greater detail.

17. Review: Cancer treatment with gas plasma and with gas plasma activated

Hassan et al. (2020)

liquid: positives, potentials and problems of clinical translation.

18. Review: The architecture and function of cardiac dyads.

Harley et al. (2020)

19. Review: Double the trouble: Giant proteins with dual kinase activity in the heart.

$\mathrm{Lu}$ and $\mathrm{Pu}(2020)$

20. Review: Nanomolar ATP binding to single myosin cross-bridges in rigor:

Grogan et al. 2020)

Pandzic et al. (2020)

A molecular approach to studying myosin ATP-kinetics using single human cardiomyocytes.

21. Review: Synthetic biology approaches to dissecting linear motor protein function: towards the design and synthesis of artificial autonomous protein walkers.

22. Review: Stochastic allelic expression as trigger for contractile imbalance in hypertrophic cardiomyopathy.

23. Review: Genetic, Clinical, Molecular and Pathogenic Aspects of the South Asian-specific Polymorphic MYBPC $3 \Delta 25 \mathrm{bp}$ Variant.

Linke et al. (2020)

Montag and Kraft (2020)

Arif et al. (2020)

return to a position involving a mixture of teaching and research. After two years at UNSW, Cris was offered a senior lectureship at his alma mater, the University of Sydney, which he took in 1974.

Cris remained at the University of Sydney from 1974 till his formal retirement in 2015 (after which he maintained his laboratory as an Emeritus Professor through to 2019). Progressing through the ranks from Senior Lecturer to Associate Professor (1986) and then Full Professor (2000), Cris trained a bevy of students along the way, with many contributing to this Special Issue. A popular lecturer, the dos Remedios seminars on comparative anatomy were notable for often containing practical dissections of the kind made famous in the early history of medicine.

On the research front, Cris continued with his research on the molecular mechanisms of human heart failure (Bao et al. 1990; dos Remedios and Moens 1995; Berry et al. 1999; Dunn et al. 2003; Ho et al. 2008; Li et al. 2012; Hamdani et al. 2013; Mollova et al. 2013; McNamara et al. 2017). However, despite having access to human hearts donated for research, Cris noted that many studies (including his own) suffered a major deficiency, in that the number of age- and sex-matched controls was severely limited and the sample storage post mortem was often not optimal. To combat this 

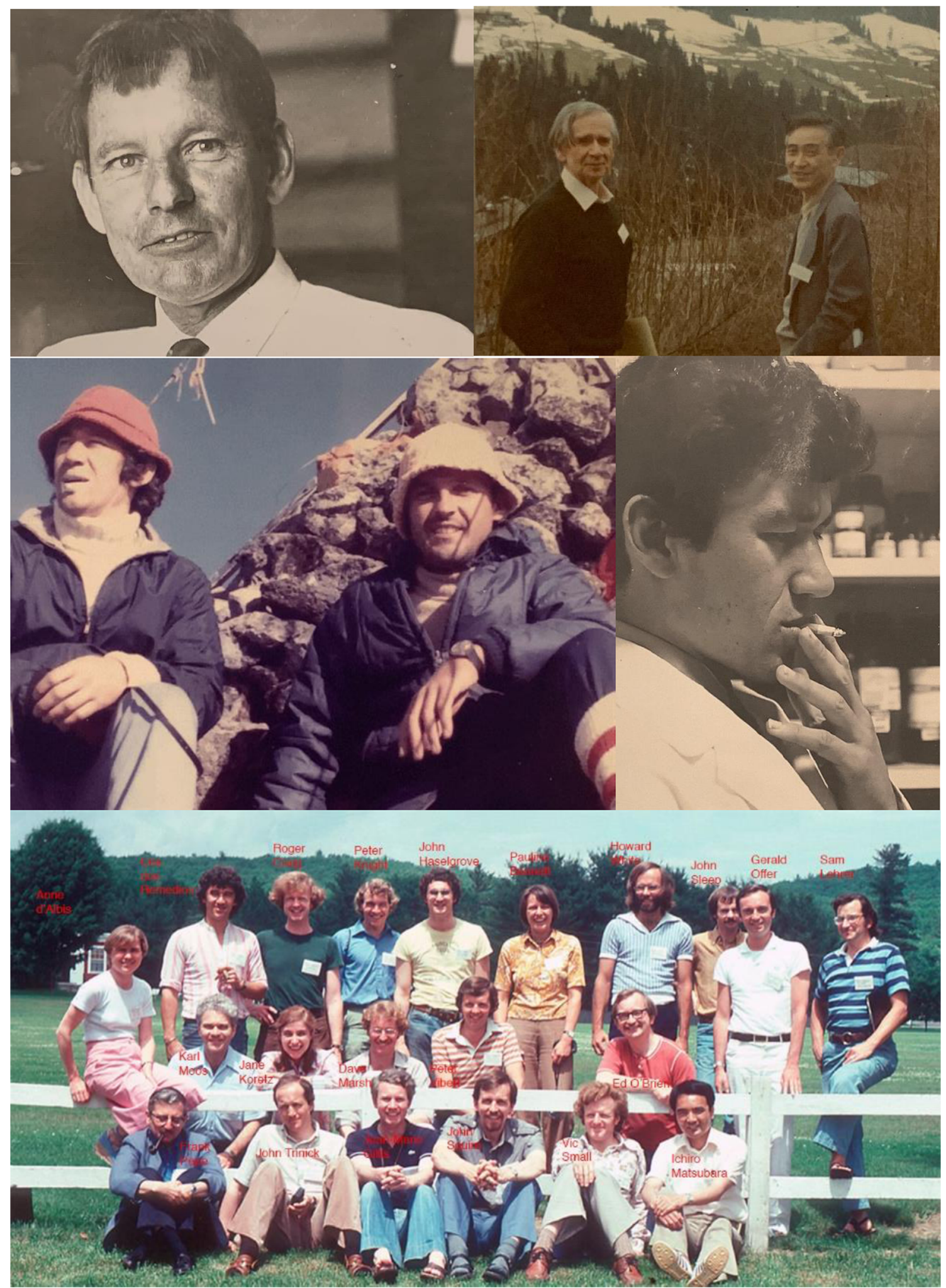

Fig. 1 Mentors and some friends and colleagues from six decades of research. PhD supervisor Prof. Darcy Gilmour University of Sydney (top left). Postdoctoral supervisor Prof. Manuel Morales in Germany in 1981 (top right). Cris together with guide in 1985 climbing Mt Wilhelm New Guinea (the second-highest mountain in the southern hemisphere) (mid left). Taking a break whilst starting the muscle research unit at the University of Sydney in 1976 (mid right). Cris with some of the postdoctoral fellows of the Morales laboratory in 1971 (bottom) (photos from personal collection of Cristobal dos Remedios) 
Fig. 2 Time spent in service of IUPAB and Biophysical Reviews. Cris together with the previous IUPAB executive in Beijing China 2009 (Prof. Gordon Roberts, Prof. Ian Smith and his wife Eva, Prof. Kuniaki Nagayama, and Prof. Patrick Cozzone and his wife Deborah) (top). Cris as Editor in Chief of Biophysical Reviews handing out journal material at the US Biophysical Society Meeting in 2009 together with Springer representative Dr. Sabine Schwarz (bottom) (photos from personal collection of Cristobal dos Remedios)

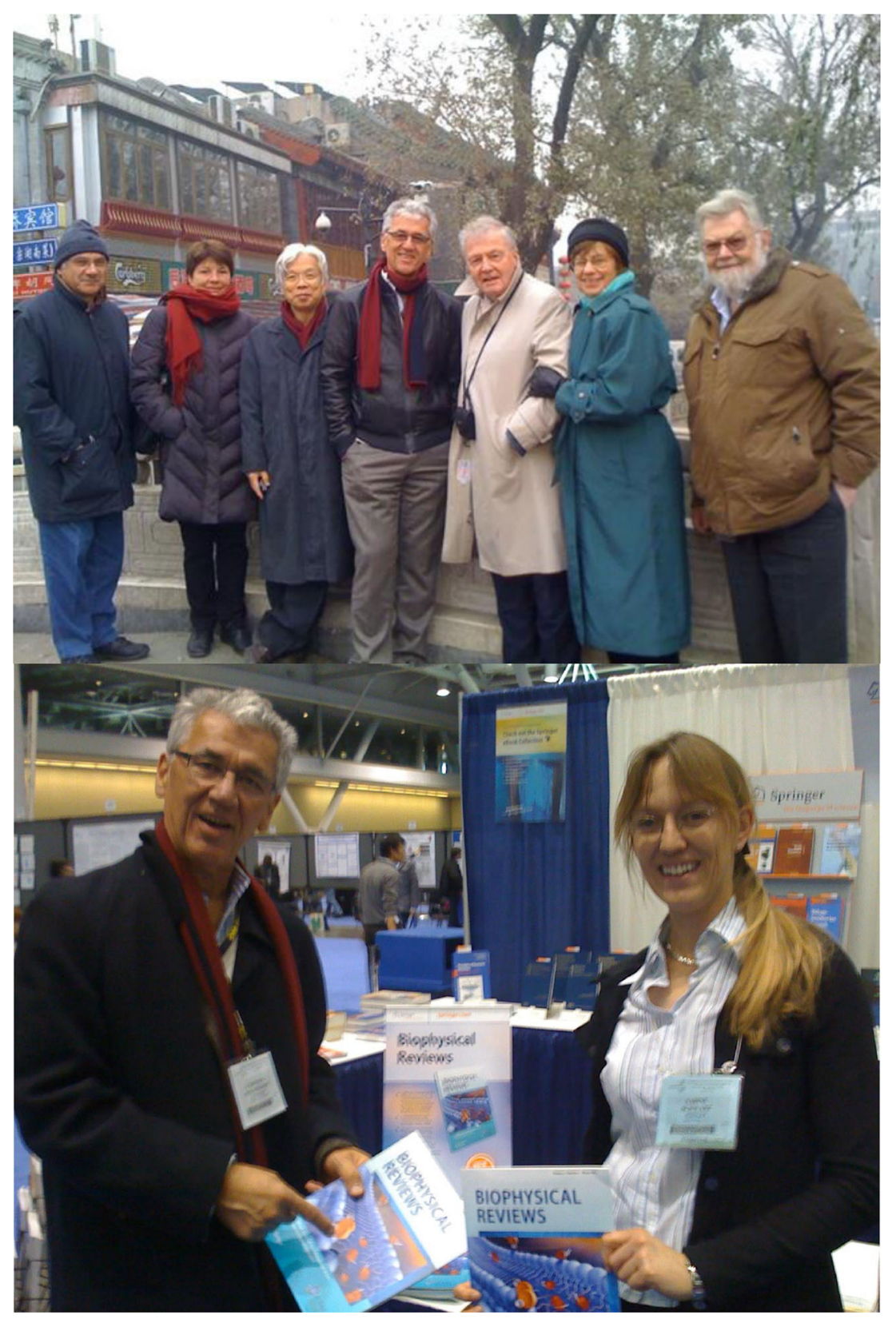

problem, Cris, together with one of Australia's most famous heart surgeons Dr. Victor Chang, personally attended human transplants and end of life surgeries to receive and properly store hearts as well as providing systematic documentation of patient histories. What started as a personal effort to improve data quality would go on to become the Sydney Heart Bankan important resource for heart researchers throughout the world (dos Remedios et al. 2017).

Another notable feature of Cris's research career in Australia was his ability to reconnect to his Japanese routes. Forming close collaborations with a number of Japanese scientists, Cris became a frequent visitor to Japan. Amongst many notable collaborations, we point out Cris's close involvement with Prof. Fumio Oosawa of Nagoya University - a giant of the actin research field.

\section{IUPAB and Biophysical Reviews}

In interacting with Cris, one often hears his critical assessment of a less than capable colleague as 'a do nothing kind of person'. This comment goes a long way to describing some of Cris's philosophy on work and science. A strong believer in the concept of scientific service, Cris has always attempted to put personal effort into the collective scientific enterprise. Part of this mentality can be recognized in Cris's activities as Director of the Bosch Institute at the University of Sydney, as a council member (2004-2008) and then Secretary-General (2008-2014) to the International Union of Pure and Applied Biophysics (IUPAB) (Fig. 2) and in his service to the Biophysical Reviews journal of which he was chief editor from 
2014 to 2018 (dos Remedios 2019). In all these associations, Cris has been an energetic advocate and genuine force for good - oftentimes propelling the structures forward through a combination of his enthusiasm and unselfish efforts, along the way creating robust structures, able to benefit the many and not just the few.

\section{'Winding down' Cris dos Remedios style}

Having fully retired from active teaching and supervision roles at the University of Sydney, Cris (at the age of 80) has recently accepted a Guest Professorship at the researchfocussed Victor Chang Heart Research Institute, located just around the corner from his former laboratory. This position has allowed Cris, in a state of semi-retirement, to perform individual research projects supported by small grants ${ }^{9}$. Still heavily involved in collaborative research, Cris's most recent research effort concerned the analysis of cardiac tissue damage arising from COVID-19 infection (Bos et al. 2020). Through telephone conversation, Cris explained that he had a hunch that related high levels of ACE2 expression on cardiac tissue to heart damage and thought that this may be an important factor in understanding the current systemic effects of the COVID-19 pandemic. Such a clear, concise, direct and enthusiastic approach to formulating hypotheses and carrying out research will be a lasting legacy of Cris dos Remedios and all the scientists he has trained through the course of his career. On the occasion of his $80^{\text {th }}$ birthday, we, along with all those contributing to this Special Issue, wish him well and continued future research success.

Acknowledgements DH acknowledges the Nagoya Institute of Technology for an appointment to their 'Visiting International Scientist' program carried out at the Department of Life Science and Applied Chemistry.

\section{References}

Ando T (2020) Studies on the impellers generating force in muscle. Biophys Rev. Current Issue

Arif M, Nabavizadeh P, Song T, Desai D, Singh R, Bazrafshan S Kumar M, Wang Y, Gilbert RJ Dhandapany PS Becker RC Kranias EG, Sadayappan S (2020) Genetic, Clinical, Molecular and Pathogenic Aspects of the South Asian-specific Polymorphic MYBPC $3 \Delta 25 \mathrm{bp}$ Variant. Biophys Rev. Current Issue

Bao S (2020) Professor Cristobal G dos Remedios mentorship? Biophys Rev. Current Issue

Bao S, King NJ, dos Remedios CG (1990) Elevated MHC class I and II antigens in cultured human embryonic myoblasts following stimulation with $\gamma$-interferon. Immunol Cell Biol 68:235-242

\footnotetext{
${ }^{9}$ Indeed, the scheduled weekly interviews conducted for this Editorial were interrupted a number of times because Cris had time on the TIRF microscope.
}

Bao S, Hu R, Hambly BD (2020) IL-34, 36 and 38 in colorectal cancer key immunoregulators of carcinogenesis. Biophys Rev. Current Issue

Barden JA, Cooke R, Wright PE, dos Remedios CG (1980) Proton nuclear magnetic resonance and electron paramagnetic resonance studies on skeletal muscle actin indicate that the metal and nucleotide binding sites are separate. Biochemistry 19:5912-5916

Bennett P (2020) Cris dos Remedios; a Driving Force in Muscle Research. Biophys Rev. Current Issue

Berry DA (2020) Recollections of my Ph D. Research in Professor Cris dos Remedios' Laboratory. Biophys Rev. Current Issue

Berry DA, Barden JA, Balcar VJ, Keogh A, dos Remedios CG (1999) Increase in expression of $\mathrm{P} 2 \mathrm{X} 1$ receptors in the atria of patients suffering from dilated cardiomyopathy. Electrophor Int J 20:2059 2064

Bos JM, Hebl VB, Oberg AL, Sun Z, Herman DS, Teekakirikul P, Seidman JG, Seidman CE, dos Remedios CG, Maleszewski JJ, Schaff HV (2020) Marked up-regulation of ACE2 in hearts of patients with obstructive hypertrophic cardiomyopathy: implications for SARS-CoV-2-mediated COVID-19. In Mayo Clinic Proceedings. Elsevier

Botts J, Cooke R, dos Remedios C, Duke J, Mendelson R, Morales MF, Tokiwa T, Viniegra G, Yount R (1973) Does a myosin cross-bridge progress arm-over-arm on the actin filament? Cold Spring Harb Symp Quant Biol 37:195-200 Cold Spring Harbor Laboratory Press

Braet F (2020) 'Muscle superman' Cristobal Guillermo dos Remedios: five decades of endless energy. Biophys Rev. Current Issue

Davey RJ, Moens PDJ (2020) Profilin: many facets of a small protein. Biophys Rev. Current Issue

Dedova I, Kekic M (2020) Cris never left you wondering about where you stood! His motto was: Just do it!. Biophys Rev. Current Issue.

Denniss AL, Dashwood AM, Molenaar P, Beard NA (2020) Sarcoplasmic reticulum calcium mishandling - central tenet in heart failure? Biophys Rev. Current Issue

Derks W, Murganti F, Bergmann O (2020) Cardiomyocyte renewal in the failing heart: lessons from the neonate? Biophys Rev. Current Issue

dos Remedios CG (1965) Comparative studies on striated muscle. PhD thesis, University of Sydney

dos Remedios CG (2019) Letter from the Editor. Biophys Rev 11:127128

dos Remedios C (2020) A Career in Biophysics. Biophys Rev. Current Issue

dos Remedios CG, Chhabra D (2007) Actin and actin-binding proteins in human disease. Springer, New York

dos Remedios CG, Cooke R (1984) Fluorescence energy transfer between probes on actin and probes on myosin. Biochim Biophys Acta (BBA) Protein Struct Mol Enzymol 788:193-205

dos Remedios CG, Gilmour D (1978) Is there a third type of filament in striated muscles? J Biochem 84:235-238

dos Remedios CG, Moens PDJ (1995) Fluorescence resonance energy transfer spectroscopy is a reliable "ruler" for measuring structural changes in proteins - Dispelling the problem of the unknown orientation factor. J Struct Biol 115:175-185

dos Remedios CG, Millikan RGC, Morales MF (1972) Polarization of tryptophan fluorescence from single striated muscle fibres. A molecular probe of contractile state. J Gen Physiol 59:103-120

dos Remedios CG, Miki M, Barden JA (1987) Fluorescence resonance energy transfer measurements of distances in actin and myosin. A critical evaluation. J Muscle Res Cell Motil 8:97-117

dos Remedios CG, Lal SP, Li A, McNamara J, Keogh A, Macdonald PS, Cooke R, Ehler E, Knöll R, Marston SB, Stelzer J (2017) The Sydney Heart Bank: improving translational research while eliminating or reducing the use of animal models of human heart disease. Biophys Rev 9:431-441

Dunn T, Heller CA, McCarthy SW, dos Remedios C (2003) Anatomical study of the "trochanteric bursa". Clin Anat 16:233-240 
Eccles J (1963) The Ionic Mechanism of Postsynaptic Inhibition. Nobel Lect 11:1963

Esfahani PH, Knöll R (2020) Cell shape: effects on gene expression and signalling. Biophysical Reviews. Current Issue

Goldberg A, Ho JWK (2020) Hactive: A smartphone application for heart rate profiling. Biophysical Reviews. Current Issue

Grogan A., Tsakiroglou P, Kontrogianni-Konstantopoulos A (2020) Double the trouble: Giant proteins with dual kinase activity in the heart. Biophysical Reviews. Current Issue

Hall D, Li A, Cooke R (2020) 'Biophysics of human anatomy and physiology - a Special Issue in honor of Prof. Cristobal dos Remedios on the occasion of his 80th birthday. Biophysical Reviews. Current Issue

Hamdani N, Krysiak J, Kreusser MM, Neef S, dos Remedios CG, Maier LS, Krüger M, Backs J, Linke WA (2013) Crucial role for Ca2+/ calmodulin-dependent protein kinase-II in regulating diastolic stress of normal and failing hearts via titin phosphorylation. Circ Res 112: 664-674

Harley JC, Suchowerska N, McKenzie DR (2020) Cancer treatment with gas plasma and with gas plasmaactivated liquid: positives, potentials and problems of clinical translation. Biophysical Reviews. Current Issue

Hassan S, Barrett CJ, Crossman DJ (2020) Imaging tools for assessment of myocardial fibrosis in humans: the need for greater detail. Biophysical Reviews. Current Issue

Ho JWK (2020) Biophysical Review's 'meet the editors series' - a profile of Joshua W. K. Ho. Biophysical Reviews. Current Issue

Ho JW, Stefani M, dos Remedios CG, Charleston MA (2008) Differential variability analysis of gene expression and its application to human diseases. Bioinformatics. 24:i390-i398

Holmes JB, Stelzer JE (2020) Prof. Cristobal dos Remedios and the Sydney Heart Bank: enabling translatable heart failure research. Biophysical Reviews. Current Issue

Ishiwata S (2020) Research Exchange with Cris: From Fluorescence Spectroscopy to Human Myocardium. Biophysical Reviews. Current Issue

Janco M, Dedova I, Bryce NS Hardeman EC, Gunning PW (2020) Visualizing the in vitro assembly of tropomyosin/actin filaments using TIRF microscopy. Biophysical Reviews. Current Issue

Kanellis VG. (2020a) Barriers to sun safety in autism spectrum disorder. Biophysical Reviews. Current Issue

Kanellis VG (2020b) Fond Memories of my PhD Research in Professor Cris dos Remedios' Laboratory. Biophysical Reviews. Current Issue

Li A (2020) Cris dos Remedios: Sydney Heart Bank and Scientific Mentorship beyond 2010. Biophysical Reviews. Current Issue

Li A, Ponten F, dos Remedios CG (2012) The interactome of LIM domain proteins: the contributions of LIM domain proteins to heart failure and heart development. Proteomics. 12:203-225

Linke H, Höcker B, Furuta K, Forde NR, Curmi PMG (2020) Synthetic biology approaches to dissecting linear motor protein function: towards the design and synthesis of artificial autonomous protein walkers. Biophysical Reviews. Current Issue

$\mathrm{Lu}$ F, Pu WT (2020) The architecture and function of cardiac dyads. Biophysical Reviews. Current Issue

Malecki C, Hambly BD, Jeremy RW, Robertson EN (2020) The RNA binding Fragile X mental retardation protein and its role beyond the brain. Biophysical Reviews. Current Issue

Marston S, Jacques A, Bayliss C, Dyer E, Memo M, Papadaki M, Messer A (2020) Donor hearts in the Sydney Heart Bank: reliable control but is it 'normal' heart? Biophysical Reviews. Current Issue
Maruyama K (1997) Connectin/titin, giant elastic protein of muscle. FASEB J 11:341-345

McNamara JW, Li A, Lal S, Bos JM, Harris SP, van der Velden J, Ackerman MJ, Cooke R, dos Remedios CG (2017) MYBPC3 mutations are associated with a reduced super-relaxed state in patients with hypertrophic cardiomyopathy. PLoS One 12:e0180064

Mollova M, Bersell K, Walsh S, Savla J, Das LT, Park SY, Silberstein LE, dos Remedios CG, Graham D, Colan S, Kühn B (2013) Cardiomyocyte proliferation contributes to heart growth in young humans. Proc Natl Acad Sci USA 110:1446-1451

Montag J, Kraft T. (2020) Stochastic allelic expression as trigger for contractile imbalance in hypertrophic cardiomyopathy. Biophysical Reviews. Current Issue

Montag J, Kowalski K, Makul M, Ernstberger P, Radocaj A, Becker JE, Tripathi S, Keyser B, Mühlfeld C, Wissel K, Pich A, van der Velden J, dos Remedios CG, Perrot A, Francino A, Navarro-Lopez F, Brenner B, Kraft T (2018) Burst-like transcription of mutant and wildtype MYH7-alleles as possible origin of cell-to-cell contractile imbalance in hypertrophic cardiomyopathy. Front Physiol 9:358

Pandzic E, Morkel CA, Li A, Cooke R, Whan RM, dos Remedios CG. (2020) Nanomolar ATP binding to single myosin cross-bridges in rigor: A molecular approach to studying myosin ATP-kinetics using single human cardiomyocytes. Biophysical Reviews. Current Issue

Parker F, Peckham M (2020) Disease mutations in striated muscle myosins. Biophysical Reviews. 12, (Current Issue).

Pruna M, Ehler E (2020) The intercalated disc - a mechanosensing signalling node in cardiomyopathy. Biophysical Reviews. Current Issue

Qian G, Ho JWK (2020) Challenges and emerging systems biology approaches to discover how the human gut microbiome impact host physiology. Biophysical Reviews. Current Issue

Seeto RK, Fleming JN, Dholakia S, Dale BL. (2020) Understanding and using AlloSure donor derived cell free DNA. Biophysical Reviews. Current Issue

Sequeira V (2020) Thank you (Obrigado) Cris and happy Bday (Parabéns)! Biophysical Reviews. Current Issue

Steenman M (2020) Insight into atrial fibrillation through analysis of the coding transcriptome in humans. Biophysical Reviews. Current Issue

Stienen GJM (2020) Early adjustments in mitochondrial structure and function in skeletal muscle to high altitude: design and rationale of the first study from the Kilimanjaro Biobank. Biophysical Reviews. Current Issue

van Dijk S (2020) The Sydney Heart Bank: a core facility that goes the extra mile to advance cardiac research. Biophysical Reviews. Current Issue

Watson S, Rozzoli K, Keogh A, Ahlston E, Scroop G, Marriott D, Fallon K, Grossman J, Allen T, Milliken E, Kidd R (2020) In Honour of Professor Cristobal dos Remedios on Behalf of The MAWA Trust. Biophysical Reviews 12, (Current Issue)

White SJ, Chong JJH (2020) Growth factor therapy for cardiac repair: an overview of recent advances and future directions. Biophysical Reviews. Current Issue

Zhazykbayeva S, Pabel S, Mügge A, Sossalla S, Hamdan N (2020) The molecular mechanisms associated with the physiological responses to inflammation and oxidative stress in cardiovascular diseases. Biophysical Reviews. Current Issue

Publisher's note Springer Nature remains neutral with regard to jurisdictional claims in published maps and institutional affiliations. 